\title{
Juan XXIII, el papa del concilio "Vino un hombre enviado por Dios cuyo nombre era Juan"
}

\author{
José Antonio de Almeida
}

1959-2011. Han pasado cincuenta y dos años, más de dos generaciones, desde que el papa Juan XXIII anunció el Vaticano II. Pudiera parecer poco tiempo, pero, dada la aceleración de la historia en que vivimos, suena como el "en aquel tiempo" con que en la liturgia se inicia la proclamación del Evangelio.

Los archivos vaticanos sobre Juan XXIII solo podrán ser abiertos a los investigadores en 2038, cuando el papa hubiera cumplido 157 años si hubiese tenido la mítica suerte de los patriarcas bíblicos. El último papa que ha tenido abiertos sus archivos fue Pío XI (1922-1939), con la autorización que, siguiendo las normas establecidas, otorgó el papa actual en 2006. Sin embargo, los estudiosos de la historia no necesitan esperar tanto tiempo para conocer y escribir sobre Juan XXIII y el concilio, de modo que ambos puedan ser mejor conocidos.

Las escasas fuentes que hemos consultado son, básicamente, textos del Instituto de Ciencias Religiosas de Bolonia, escritos por el profesor Giuseppe Alberigo (1926-2007), su representante más insigne'. Los Ricordi dal concilio,

1. Es sabido que la "vida de Juan XXIII" — aquí no se puede dejar de pensar en la controversial cuestión del "Cristo de la fe" y el "Jesús de la historia"- del Instituto de Ciencias Religiosas de Bolonia no es considerada como la única ni la mejor, ni la que expresa la pre-comprensión con la que trabaja el autor. Véase G. Alberigo, Papa Giovanni (1881-1963), EDB, Bolonia, 2000; G. Alberigo, Breve historia del Concilio Vaticano II (1959-1965), Il Mulino, Bolonia, 2006; G. Alberigo (coord.), Storia del Concilio Vaticano II, 5 vols., EDB, Bolonia, 1995-2001; G. Alberigo (coord.), Jean XXIII devant l'histoire, Seuil, París, 1989; G. Alberigo (coord.), História dos Concílios Ecumênicos, Paulus, São Paulo, 1995; A. Alberigo y G. Alberigo, Giovanni XXIII. Profezia nella fedeltà, Queriniana, Brescia, 1978; G. Alberigo y A. Melloni, Fede Tradizione Profezia, Studi su Giovanni XXIII e sul Concilio, Morcelliana, Brescia, 1984; J. O. Beozzo, A Igreja do Brasil no Concílio Vaticano II (1959-1965), Paulinas, 
del secretario particular de Roncalli de 1953 a 1963 Loris Francesco Capovilla ${ }^{2}$, quien todavía vive en Sotto il Monte, aldea natal de Angelo Giuseppe Roncalli y que lleva bien sus 95 años. Y finalmente, la biografía oficial para la beatificación de Juan XXIII'.

La ocasión nos la ofrece el aniversario de los 50 años de la apertura del Vaticano II, el 11 de octubre de 1962, lo que con seguridad promoverá nuevos estudios sobre la vida, la figura y la obra del papa del concilio.

\section{El anuncio "programático"}

Era la tarde del 25 de enero de 1959, fiesta de la conversión de San Pablo. El papa se encontraba en Roma en la iglesia de la abadía de San Pablo extra muros. Al terminar la misa con la que concluía la 51. ${ }^{a}$ Semana de Oración por la Unidad de los Cristianos, ante un pequeño grupo de cardenales - diecisiete en total- Juan XXIII, consciente de ser el "obispo de Roma ${ }^{4}$ y pastor de la

São Paulo, 2005; A. Melloni y E. G. Ruggieri (eds.), Chi ha paura del Vaticano II?, Carocci, Roma, 2009. En los últimos tiempos viene creciendo otra línea interpretativa que trabaja sobre otros presupuestos y otra metodología: W. Kasper, Theologie und Kirche, Mainz, 1987, pp. 290-299; D. Berger, "Gegen die Tradition oder im Licht der Tradition? $\mathrm{Zu}$ neueren Interpretationen des Zweiten Vatikanischen Konzils", Divinitas, 40 (2005), pp. 294-316; A. Marchetto, Il Concilio Ecumenico Vaticano II. Contrappunto per la sua storia, Libreria Editrice Vaticana, Città del Vaticano, 2005; B. Gherardini, Concilio Vaticano II. Um discorso da fare, 2009; R. de Mattei, Concilio Vaticano II. Uma storia mai scritta, Lindau, Torino, 2010.

2. L. F. Capovilla, Ricordi dal concilio. Siamo appena all'aurora, La Scuola, Brescia, 2011.

3. M. Benigni y G. Zanchi, João XXIII, Paulus, Apelação (Portugal), 2000.

4. En su primer discurso oficial tras ser elegido, Juan XXIII se presentó como obispo de Roma. Algunos días después, en la toma de posesión de la catedral de San Juan de Letrán — catedral de Roma - con elegancia hizo ver que sus predecesores pudieron omitir o dar menor importancia a tal acontecimiento, que él quería rescatar en su pleno significado: "El papa es auténticamente y no solo simbólicamente obispo de Roma" (G. Alberigo, Papa Giovanni (1881-1963), op. cit., p. 140). "Se sabe también que había pensado dividir su residencia entre el Vaticano y Letrán, para mostrar que él era obispo de Roma, pero eso no pasó de ser un sueño ( $c f$. G. Gennari, "Cuando Ratzinger era considerado un 'pericoloso teologo d'oltralpe', Affari.it, 12 de marzo de 2011). Como no era viable, multiplicó sus visitas, públicas y privadas, a escuelas, asilos, prisiones, parroquias, lo que llevó a que le dieran el simpático nombre de "Giovanni fuori le mura" ( $c f$. M. Benigni y G. Zanchi, João XXIII, op. cit., pp. 267-271). Coherentemente con esta convicción, el 12 de junio de 1962, decidió transferir a San Juan de Letrán toda la estructura del vicariato de la diócesis, acentuando la autonomía de la curia diocesana y traduciendo, también a nivel burocrático, la unidad, la diferencia y la articulación, en la Iglesia de Roma y en la persona de su obispo, de las instancias local y universal de la Iglesia (cf. ibid., p. 178). 
Iglesia universal", dibujó un breve cuadro de la situación de Roma y del mundo, y concluyó:

Esta constatación despierta en el corazón... una resolución firme (una risoluzione decisa) de volver a algunas formas antiguas de afirmación doctrinal y de sabios ordenamientos de disciplina eclesiástica, que en la historia de la Iglesia, en épocas de renovación, dieron frutos de extraordinaria eficacia para la claridad de pensamiento, la solidez de la unidad religiosa y una llama más viva de fervor cristiano.

¿Cuáles podrían ser esas formas antiguas que "en la historia de la Iglesia, en épocas de renovación", dieron frutos tan formidables? Con excepción de Tardini, el secretario de Estado a quien pocos días antes había confiado su decisión, ninguno de los presentes podía sospechar lo que el papa tenía en mente: "Pronunciamos ante ustedes, temblando con un poco de conmoción, pero al mismo tiempo con humilde firmeza de propósito (con umile risolutezza di propósito), el nombre y la propuesta de una doble celebración: un sínodo diocesano para la Urbe y un concilio general para la Iglesia universal".

La fiesta de la conversión de San Pablo - había dicho el papa al inicio de su intervención - "nos sugirió abriros nuestra alma, confiando en vuestra bondad y comprensión, sobre algunos puntos más luminosos de la actividad apostólica que nos han sugerido estos tres meses de presencia y de contacto con el ambiente eclesiástico romano (...) para que el nuevo pontificado responda clara y definidamente a las exigencias espirituales de la hora presente"

No mucho después, en 1961, dirá que "el concilio pretende construir un edificio nuevo sobre los fundamentos que se han establecido a lo largo de la historia... dilatará la caridad a las variadas necesidades de los pueblos y les propondrá el mensaje de Cristo de manera clara"6. Lo que hizo madurar en Juan XXIII la idea de celebrar el concilio como "la más válida respuesta colegial a las expectativas" de la Iglesia y del mundo fue "el profundo conocimiento de los acontecimientos eclesiales, especialmente en períodos cruciales de transformaciones y evoluciones al interior de la Iglesia7; la conciencia, teológicamente

5. "L'annuncio del concilio ecumenico", en A. Alberigo y G. Alberigo, Giovanni XXIII, op. cit., pp. 274-278 (las itálicas son del autor).

6. Discorsi Messaggi Coloqui di Giovanni XXIII, Roma, 1960-1963, t. IV, pp. 503-505. En adelante, referido simplemente como DMC.

7. Roncalli era muy familiar con la historia de la Iglesia ( $c f$. A. Melloni, "Formation et développement de la culture de Roncalli", en G. Alberigo (coord.), Jean XXIII devant l'histoire, op. cit., pp. 219-259. Se dedicó especialmente al estudio de san Carlos Borromeo (1538-1584) y del oratoriano cardenal Cesare Baronio (1538-1607), considerado el padre de la moderna historiografía de la Iglesia, investigando los documentos según los criterios científicos (cf. M. Benigni y G. Zanchi, João XXIII, 
basada, de manera especial, en la lectura de los Padres, de la corresponsabilidad colegial en el gobierno de la Iglesia de parte de todo el episcopado y, de alguna manera, de todo el pueblo de Dios; la fe certísima y radical en la asistencia del Espíritu Santo a su Iglesia, particularmente en los momentos de crisis pastorales graves".

El anuncio de un concilio ecuménico, hecho por un "papa de transición" y casi octogenario - consciente, sin embargo, de las prerrogativas del primado, de la naturaleza excepcional de su propuesta y del carácter definitivo de su decisión— tomó a todos por sorpresa.

\section{Las primeras reacciones}

"Humanamente" — dirá el papa el 8 de mayo de 1962 - "podría pensarse que los cardenales, tras haber escuchado la alocución, se arremolinarían a nuestro alrededor, mostrando aprobación y deseándonos fortuna. Pero sucedió todo lo contrario: un silencio impresionante y reverencial. Solo en los días siguientes pudimos entender lo que había ocurrido cuando nos hablaron en privado los purpurados que estaban presentes en la audiencia. 'La conmoción había sido tan intensa y el gozo tan profundo (...) que no encontrábamos palabras adecuadas para expresar el júbilo y la obediencia total"'".

Tampoco se hicieron esperar otras reacciones. El cardenal Spellman, de Nueva York, responsabilizó a personas poco inteligentes de lo que había hecho un papa ingenuo y manipulable: "No creo que el papa pretendiese convocar un concilio, a no ser que haya sido forzado por personas que interpretaron mal sus palabras". El cardenal Lercaro, arzobispo de Bolonia, uno de los futuros líderes de la mayoría conciliar y pieza clave en la conducción de los debates sobre la reforma litúrgica y sobre los pobres, tampoco ocultó su sorpresa:

¿Cómo puede (el papa) tener la audacia de convocar un concilio, después de cien años, y solo a tres meses de su elección? El papa Juan es precipitado y compulsivo. Su inexperiencia y su falta de conocimientos lo conducen a dar este paso, a esta paradoja. Sin duda, un acontecimiento como este arruinará su ya frágil salud y hará que se derrumbe el edificio de su presunta virtud moral y teológica.

Ni siquiera Montini, arzobispo de Milán, amigo de muchísimos años de Juan XXIII, y quien llevará a término el concilio en el siguiente pontificado, tuvo una reacción serena. Al enterarse de la noticia, a la noche llamó a su viejo amigo y

op. cit., pp. 39-48). Al inicio de su ministerio sacerdotal, fue profesor de historia de la Iglesia en el seminario mayor de Bérgamo ( $c f$. ibid., pp. 85 y ss.).

8. L. F. Capovilla, Ricordi dal Concilio, op. cit., p. 54.

9. DMC, IV, p. 259. 
confidente, el P. Julio Bevilacqua, futuro cardenal: "Este viejo, santo e infantil, parece no entender en qué avispero nos está metiendo". Bevilacqua respondió sabiamente: "No se preocupe, padre Batista, déjelo estar. El Espíritu todavía está despierto en la Iglesia" ${ }^{\prime 10}$. A un miembro de la curia, quien, semanas después, recordó a Juan XXIII que preparar el Vaticano I había llevado seis años, y que por lo tanto sería imposible pensar en un concilio antes de 1963, el papa le respondió con su acostumbrado buen humor: "iExcelente! ;Entonces, comenzaremos en 1962!". A finales de los años 60 aumentaron las críticas a la convocatoria del concilio y sus resultados. Dieron la vuelta al mundo ${ }^{11}$ las agrias palabras del cardenal Siri, uno de los mayores exponentes del conservadurismo católico: "La Iglesia necesitará 50 años para recuperarse de los caminos equivocados por los que está transitando Juan XXIII"12.

La reacción entre los obispos fue lenta. La mayoría de ellos estaban demasiado integrados en el sistema eclesiástico, vigente desde hacía siglos y reforzado después del Vaticano I, sobre todo durante el pontificado de Pío XII, para darse cuenta de la dimensión y relevancia de lo que el papa estaba proponiendo. El centralismo romano y la ideología infalibilista llevaron, quizás, a que muchos obispos pensaran que tras el concilio de Pío IX bastaría con leer los periódicos durante el desayuno para saber lo que quería el papa y para llevarlo fielmente a la práctica. En 1869 Joseph Maistre (1753-1821) escribió: “¡Por qué un concilio, cuando es suficiente una cartelera de avisos [nota del autor]?"13.

10. Cf. A. Fappani y F. Molinari (eds.), Giovanni Battista Montini Giovane, 1897-1944: documenti inediti e testimonianze, Torino, 1979, p. 171 (citado por M. Benigni y G. Zanchi, João XXIII, op. cit., p. 253).

11. Cf. R. Amerio, Jota unum. Studio sole variazioni della chiesa cattolica nel secolo XX, Ricardo Ricciardo Edizioni, Milano, 1985.

12. Otra versión: "La Iglesia necesitará cuarenta años para recuperarse de los caminos equivocados que Juan XXIII ha recorrido en cuatro".

13. En este texto y otros el autor traduce libremente alguna expresión. Por eso dice nota del autor. J. de Maistre, Du Pape, 1, II, c. 15, 1869, p. 276, nota 1. "El concilio universal se tornó inútil y superfluo para la Iglesia católica" (P. Hinschius, Kirchenrecht, t. III, 1883, p. 630). "Los concilios no son necesarios para la Iglesia... La Iglesia posee en el primado del pontífice romano el órgano para el tiempo ordinario y esencial de la autoridad suprema, y este órgano tiene por sí mismo poder y gracia para resolver todas las cuestiones, promulgar leyes universales y responder a todos los problemas" (J. Forget, "Conciles", en Dictionnaire de théologie catholique, col. 669, citado por G. Alberigo, Jean XXIII devant l'histoire, op. cit., p. 202). En 1923, el cardenal Billot afirmaba que, con el dogma de la infalibilidad papal, se había dicho la palabra final a la época de los concilios, que, además, eran "caros, incómodos, llenos de problemas y peligros de todo tipo" (cf. Civiltà Cattolica (1969), II, pp. 123 y 132). Una pléyade de ponderaciones semejantes sobre lo innecesario de un concilio después del Vaticano I se encuentran en Y. Congar, Le Concile de Vatican 
En las semanas siguientes la reacción de los cardenales que estuvieron presentes en el anuncio del concilio, la de otros cardenales y la del Osservatore Romano mostró algo que iba a ser característico del pontificado de Juan XXIII:

(...) la sordera de algunos sectores de la estructura central de la Iglesia universal. No era nada nuevo, sobre todo después del Vaticano I y el énfasis que se ponía frecuentemente en la estrecha unidad entre la curia romana y el papa. Roncalli no era un novato en tener dificultades con la curia, tras treinta años en el servicio diplomático de la Santa Sede. Pero sí le sorprendió y le desagradó esa actitud, pues ahora desempeñaba un servicio institucional sólido, un servicio papal. Y además, no pensaba desistir. ${ }^{14}$

Diferente fue la reacción de personas y grupos en la Iglesia católica, activos desde hacía décadas en movimientos de renovación social, laical, litúrgica, patrística, bíblica, misionera y ecuménica. Juan XXIII los conocía desde los comienzos de su ministerio sacerdotal junto al obispo de Bérgamo, Giacomo Radini Tedeschi, líder del movimiento católico italiano ${ }^{15}$. En esos círculos la decisión papal fue vista con gran simpatía, y muy pronto vieron en ella la oportunidad de dar una respuesta institucional y un impulso decisivo a sus problemas ${ }^{16}$. Los ambientes teológicos propiamente dichos, "que percibieron más rápidamente la novedad del pontificado y del anuncio, se pusieron a ordenar las ideas, sin terminar de creer que, efectivamente, se habían abierto espacios de renovación"'17.

En el movimiento ecuménico el impacto fue inmediato.

II. Son Église peuple de Dieu et corps du Christ, Beauchesne, París, 1984, pp. 51-52, especialmente la nota 7 de la p. 51.

14. G. Alberigo, Giovanni XXIII (1881-1963), op. cit., p. 145.

15. "Con Radini, Roncalli hace la experiencia del 'pensar grande', ve la actuación de un pastor comprometido sin reservas, entra en contacto con preocupaciones litúrgicas y ecuménicas poco comunes en Italia y comparte las primeras y fascinantes experiencias de acción católica, entrando en contacto con animados ambientes de 'feministas' católicas..." (G. Alberigo, Giovanni XXIII [1881-1963], op. cit., p. 39). Después, sus actividades con la juventud, con las misiones, como diplomático en Bulgaria (ortodoxia), en Turquía (islamismo) y, sobre todo, en la Francia de la posguerra, lo ponen en contacto no solo con los fermentos de renovación que despertaban en la Iglesia, sino también con problemas y procesos mucho más complejos ( $c f$. ibid., pp. 49 y ss., 57 y ss., 63 y ss., 81 y ss., 101 y ss.).

16. "Al inicio del pontificado de Juan XXIII existía un fuerte deseo de reforma, pero no había ningún tipo de petición difusa de un nuevo concilio general. Lo que preparó el concilio Vaticano II no fue la petición de un concilio, sino justamente las ideas de reforma y las transformaciones que estas estaban lentamente produciendo" (K. Schatz, Storia dei concili. La chiesa Nei suoi punti focali, EDB, Bolonia, 1999, p. 249; cf. O. H. Pesch, Il Concilio Vaticano II. Preistoria, svolgimento, risultati, storia post-conciliare, Queriniana, Brescia, 2005, pp. 12-69).

17. G. Alberigo, Breve storia del Concilio Vaticano II, op. cit., p. 30. 
Que el papa fuera [tras más de un siglo de hostilidad hacia el movimiento ecuménico $]^{18}$ a tomar la iniciativa de la unión de las iglesias cristianas y a concebir el proceso en términos de "cooperación" con el deseo de un "único rebaño" [no de un "único redil"], y no ya en términos de "regresar a", fue algo tan inesperado, y prácticamente inverosímil, que llegó a despertar reacciones disparatadas y a exigir repensar toda la estrategia ecuménica. ${ }^{19}$

Pero, evidentemente, no todo eran flores. Se temía que la iniciativa del papa pudiera esconder intenciones de dominio y de que otros cristianos quedaran absorbidos por la Iglesia romana. Se ponía alerta contra un irenismo fácil y funesto. Se dejaba en claro que los problemas en el caminar ecuménico eran serios, y que debían enfrentarse con sinceridad y realismo.

Y fue sorprendente que en una sociedad cada vez más secularizada en términos políticos y culturales el anuncio de un "concilio" haya despertado en la opinión pública atención, interés y hasta expectativas. Aunque no entendiese bien de qué se trataba, el gran público

en la iniciativa del anciano pontífice había captado instintivamente un hecho lleno de significado, había leído un signo de esperanza, de confianza en un futuro de renovación. Además, se pudo percibir una voluntad, quizás también ingenua, pero auténtica, de involucrarse y de participar, y con la sensación de que sería acogida. Prácticamente sin mediaciones, la iniciativa del Papa llegaba a millones de mujeres y hombres, y les convenció de su alcance liberador e innovador. ${ }^{20}$

Ni la política ni las ideologías quedaron fuera a la hora de apreciar el anuncio del papa, viniese de un político católico como el futuro prefecto de Florencia Giorgio La Pira, o de los más altos dirigentes soviéticos en Moscú ${ }^{21}$.

\section{3. ¿Qué concilio?}

Entre el anuncio (25 de enero de 1959) y la inauguración (11 de octubre de 1962) del concilio transcurrieron dos años y medio.

18. Cf. G. Ceretti, Molte chiese cristiane un unica chiesa di Cristo. Corso di ecumenismo, Queriniana, Brescia, 1992, especialmente pp. 34-41.

19. G. Alberigo, Breve storia del Concilio Vaticano II, op. cit., p. 23. Debido a la mención de los "hermanos separados" en el mismo anuncio del concilio y a la insistencia del papa en la unidad de los cristianos, pronto se fue disipando, dentro y fuera de la Iglesia, la confusión entre "concilio ecuménico", "concilio de unión" y "concilio para la unión” (cf. G. Alberigo, Giovanni XXIII [1881-1963], op. cit., pp. 159 y ss.; O. H. Pesch, Il Concilio Vaticano II, op. cit., pp. 48 y ss.).

20. G. Alberigo, Breve historia del Concilio Vaticano II, op. cit., p. 24.

21. Ibid., pp. 22, 25. 
Ante todo, había que caracterizar mejor el concilio anunciado. Los elementos contenidos en el anuncio decían mucho y al mismo tiempo decían muy poco. Después de la primera reacción global, parecía que nadie sabía a ciencia cierta qué decir. ¿Callaban por no contrariar al papa, quien en poco tiempo había ganado una inmensa simpatía? ¿Callaban con la esperanza de que el anuncio de un concilio caería en el vacío? ¿Callaban desorientados ante la sorpresa de la nueva perspectiva que se anunciaba? ¿No sabían qué hacer con la libertad, tras siglos de rígido encuadramiento institucional?

Pronto, sin embargo, la intuición inicial fue adquiriendo contornos más definidos. Las primeras luces llegaron en los últimos días de abril de 1959. La finalidad fundamental del concilio sería que aumentara el trabajo de los cristianos por "dilatar los espacios de la caridad... con claridad de pensamiento y con grandeza de corazón" 22 . Iba a ser, claro está, un concilio de obispos, pero con la participación de representantes de comunidades cristianas no católicas. Gozaría de plena libertad y, por ello, tendría poderes eficazmente deliberativos. Y de ahí la necesidad de distinguir clara y constantemente entre concilio y curia. Una manera sutil - ipero firme! ${ }^{23}$ - de afirmar la jindependencia del concilio! El concilio, por su propia naturaleza, tendrá estructura y vida propias. La curia será responsable de la gestión ordinaria de la vida de la Iglesia, renunciando a cualquier veleidad de apoderarse del concilio o de manipularlo. Más aún, el papa de "transición" quiere un concilio de "transición epocal", es decir, que

haga que la Iglesia transite de la época postridentina, y en cierta medida de una época plurisecular costantiniana, a una nueva época de testimonio y de anuncio, con la recuperación de los elementos de la tradición fuertes y permanentes, que sean idóneos para alimentar y garantizar la fidelidad evangélica en una transición tan ardua. ${ }^{24}$

El concilio, repite el papa frecuentemente, deberá ser un "nuevo Pentecostés". En la oración por el concilio, se pide que el Espíritu Santo renueve "en nuestra época prodigios como los de un nuevo Pentecostés" 25 . La obra del concilio — dirá Juan XXIII el 13 de noviembre de 1960 - está completamente volcada a que la Iglesia viva de sus fuentes: reconducir "la Iglesia de Jesús a las líneas más puras

22. DMC I, p. 903.

23. "El concilio ecuménico tiene una estructura y organización propia, que no puede ser confundida con la función ordinaria y característica de los varios dicasterios o congregaciones, que constituyen la curia romana... Por tanto, hay que distinguir con precisón: uno es el gobierno ordinario de la Iglesia, de lo que se ocupa la curia romana, y otro el concilio" ("João XXIII. Preparazione, mete, speranze del concilio ecumenico, 5 de junho de 1960", en A. Alberigo y G. Alberigo, Giovanni XXIII, op. cit., p. 325).

24. G. Alberigo, Breve storia del Concilio Vaticano II, op. cit., p. 26.

25. DMC IV, 875. 
de su nacimiento"26. "Más que uno u otro punto de doctrina o de disciplina... se trata de rescatar el valor y esplendor de la sustancia del pensar y del vivir humano y cristiano..." ${ }^{27}$. Resumiendo, de diversos textos se desprende el carácter pastoral del Vaticano II: "Por su propia naturaleza, ipastoral!"28.

\section{La fase ante-preparatoria: consulta amplia y abierta}

Significativamente, en la solemnidad de Pentecostés de 1959, y de nuevo de forma inesperada, el papa hizo pública la decisión de instituir la comisión antepreparatoria. Sin embargo, su composición parecía estar en clara contradicción con lo que el propio papa había dispuesto sobre la independencia del concilio. En efecto, seguía los mismos moldes de preparación del Vaticano I, y estaba monopolizada por la curia. Era una pequeña comisión de diez miembros, casi solo italianos y romanos, representando a todas las congregaciones de la curia, con el cardenal Domenico Tardini, secretario de Estado, como presidente, y con Pericle Felici, asesor de la Sagrada Rota, como secretario. Su tarea era recoger material para la "preparación próxima" de los trabajos conciliares, delinear los temas a ser tratados en el concilio y formular propuestas para la composición de los órganos responsables de la preparación propiamente dicha.

La comisión pensó en preparar un cuestionario, definió algunos "temas probables" e incluso pensó en establecer una relación entre los temas y las respectivas congregaciones romanas. Las reacciones críticas no se hicieron esperar: ¿cómo se explica que la preparación de un concilio universal de obispos sea confiada a un reducidísimo grupo de altos burócratas, quienes en su mayoría ni siquiera son obispos?

Sin embargo, también en esto el papa mostró el temperamento ${ }^{29}$ y la sabiduría del historiador, del diplomático y del hombre de Iglesia, condensados en Juan XXIII. La organización y el proceso contenían algunas novedades que fueron decisivas: la secretaría de Estado - más próxima y más identificada con él- y no el Santo Oficio (la antigua Inquisición y la actual Congregación de la Doctrina de la $\mathrm{Fe}$ ) era responsable de la conducción de esta fase preparatoria. La elección de miembros de la curia era un gesto de confianza, inspirado por el deseo y

26. DMC III, 5.

27. DMC III, 18.

28. DMC V, 516.

29. "Agradezco al Señor el temperamento que me dio... Me siento en obediencia en todo, y constato que esta actitud, in magnis et minimis, confiere a mi pequeñez tanta fuerza de audaz simplicidad que, siendo toda evangélica, solícita, y obteniendo respeto general, y es motivo de edificación para muchos... En la mansedumbre y en la humildad del corazón, está la gracia del recibir, del hablar, del tratar, la paciencia del soportar, del compadecer, del callarse, y de la valentía..." (Diario del Alma, 29 de noviembre-10 de diciembre de 1959). 
la esperanza de ganarse la lealtad de la curia en relación con el concilio ${ }^{30}$. La consulta debía ser lo más amplia posible y no limitarse solo a algunas personas, como ocurrió en el Vaticano I ${ }^{31}$. El papa descartó la hipótesis del cuestionario, invitando por el contrario a que cada uno indicase, con plena libertad, los temas que el concilio debería $\operatorname{tratar}^{32}$. Con el nuevo papa, ¡Roma no mandaba, sino que pedía sugerencias ${ }^{33}$ !

Cuando el 14 de julio de 1959 el papa comunicó al cardenal Tardini el nombre del futuro concilio - Vaticano II- quedó claro que no se trataba de retomar el Vaticano I, que no pudo ser concluido a causa de la toma de Roma en septiembre de 1870 por las tropas italianas comandadas por el general Cardona. Sería un concilio nuevo, con una agenda abierta, en otro clima: era una página en blanco para ser escrita por los obispos de una Iglesia no solo universal, sino ahora, por fin, también mundial (Weltkirche).

\section{La fase preparatoria: el trabajo de las comisiones pre-conciliares}

La preparación propiamente dicha fue confiada el 5 de junio de 1960 a una comisión central y diez comisiones (grupos de trabajo) para las diversas áreas temáticas. Las comisiones continuaron siendo presididas por los cardenales que presidían las respectivas congregaciones de la curia. Pero hubo una novedad

30. El juicio sobre el secretario particular, por lo que toca a la curia, es benévolo: "Al lado de comprensibles titubeos, la colaboración —así creo - fue leal, mayor de lo que se quiera admitir" (L. F. Capovilla, Ricordi dal Concilio, op. cit., p. 50).

31. Mientras que antes del Vaticano I fueron consultados solo 47 obispos, ahora la consulta incluyó a todos los obispos, los superiores de las órdenes y congregaciones religiosas, las facultades eclesiásticas. Entre 1959 y 1960, de un total de 2,800 personas preguntadas, respondieron 2,150. En general, las indicaciones eran repetitivas, poco innovadoras y marginales (cf. K. Schatz, Storia dei concili, op. cit., p. 260).

32. "Él quiere ser un instrumento del Espíritu y por eso decide no imponer al concilio y a la Iglesia un programa rígido; se propone, por el contrario, suscitar una actitud de escucha y de disponibilidad; el resto se iría clarificando en la medida en que caminasen las cosas" (G. Alberigo, Giovanni XXIII [1881-1963], op. cit., p. 146).

33. Las sugerencias, analizadas y clasificadas entre el inicio de septiembre de 1959 y el final de enero de 1960, produjeron un índice con 18 divisiones temáticas, titulado "Síntesis analítica de los consejos y sugerencias dados por los obispos y prelados", que ocupa más de 1,500 páginas. Enseguida se elaboraron síntesis por grandes áreas geográficas, que fueron leídas personalmente por Juan XXIII entre el 13 de febrero y el 1 de abril. El trabajo de la comisión ante-preparatoria terminó con la redacción de una breve "Síntesis final de los consejos y sugerencias de los excelentísimos obispos y prelados de todo el mundo para el futuro concilio ecuménico". A partir de esos elementos, en el mes de julio, el secretariado de la comisión preparó las "Cuestiones presentadas a las Comisiones preparatorias del concilio": 54 temas divididos en 11 grupos. 
notable: la inclusión entre las comisiones de una comisión del apostolado de los laicos bajo la presidencia del cardenal F. Cento, y otra, del recién creado secretariado para la unidad de los cristianos, presidida por el cardenal Agustín Bea, exrector del Pontificio Instituto Bíblico. Al poco tiempo, no sin dificultades y a través de sucesivas nominaciones, aquella estructura tradicional quedó liberada del total monopolio de la curia y de los ambientes romanos ${ }^{34}$. Por un lado, la comisión central quedó internacionalizada al ingresar en ella obispos del mundo entero. Por otro, teólogos de diversas tendencias, incluso algunos que bajo Pío XII habían sido objeto de sanciones romanas, pasaron a participar en los trabajos preparatorios.

En poco más de dos años, a partir de las "Quaestiones" de 1960 las comisiones preparatorias elaboraron cerca de setenta esquemas. En general, repetían las enseñanzas doctrinales y disciplinares de los últimos papas, sobre todo de Pío XII, con la convicción de que el concilio —que en los ambientes conservadores se creía y se deseaba que ifuese breve! - las habría de refrendar ${ }^{35}$. Esta fase terminó con el motu proprio "Concilium", en el que Juan XXIII, el 2 de febrero de 1962, establecía el 11 de octubre como día de la apertura de la asamblea conciliar.

Varias cosas fueron quedando claras. (1) El Vaticano II no iba a ser un "concilio de unión" entre las Iglesias ${ }^{36}$, pero sí debía marcar un cambio en la disponibilidad católica a involucrarse profundamente en el proceso ecuménico, sobre todo a través del "aggiornamento" de la Iglesia católica. (2) El concilio llevaría la marca de la "pastoralidad" ${ }^{37}$, como no se cansaba de repetir Juan

34. Ya hemos dicho que el juicio de Capovilla por lo que toca a la curia es más benévolo.

35. Como en la época del Vaticano I, cuando, irónicamente, el general de los redentoristas podía escribir a Dechamps, arzobispo de Malines: "En Roma, todo está tan bien preparado que los Padres no tendrán sino que votar" (M. Becqué, Le Cardinal Dechamps, t. II, p. 157; citado por G. Thils, L'ecclesiologia del Concilio Vaticano I. Preparazione, risultati, problemi, en Facoltà Teologica Interregionale Milano, La Scuola, Brescia, 1973, p. 9).

36. Concilio de "unión" habría sido a su modo el Lionés II (1274), aunque sus resultados fueran efímeros. La unión con los griegos fue efímera, ya sea porque respondía más a intereses políticos que religiosos, o porque el episcopado griego, terminado el concilio, no reconoció sus decretos, o porque no se quiso enfrentar la profundidad teológica de las cuestiones, sobre todo la notoria diferencia eclesiológica entre Occidente y Oriente ( $c f$. G. Alberigo (coord.), História dos Concílios Ecumênicos, op. cit., p. 210).

37. "Pastoral" expresa "la dimensión central de la eclesiología de Roncalli, que quería calificar el concilio que convocó como 'concilio pastoral'. 'Pastoral' y los vocablos de la misma raíz ocupan un lugar muy importante en el vocabulario roncalliano. Aparecen constantemente a lo largo de los numerosísimos escritos suyos con casi dos mil entradas, de acuerdo a la concordancia verbal establecida por A. Melloni 
XXIII: en lugar de la clásica díada "doctrina-disciplina", la asamblea conciliar debería mirar hacia adelante —en ese momento histórico nuevo y particularmente propicio-, al proponer las exigencias de la vida de la Iglesia y sus relaciones con la sociedad, consideración inspirada evangélicamente en la caridad, para que así transparente en todo al Cristo "buen Pastor"38. (3) Los padres conciliares serían los protagonistas del concilio, actuando con plena libertad y saliendo de la pasividad en la que estaban sumidos ${ }^{39}$.

en el Istituto per le Scienze Religiose de Bolonia" (G. Alberigo, Jean XXIII, op. cit., p. 206). "La pastoralidad atribuida al nuevo concilio por el papa como característica dominante, ¿qué quería decir? Durante mucho tiempo fue banalizada y comprendida como un modo de poner el concilio en un nivel no-teológico, puramente operativo... Solo en la inmediata proximidad del concilio se abrió camino la acepción fuerte de 'pastoralidad' como subordinación de cualquier otro aspecto de la vida de la Iglesia a la imagen exigente de Cristo como 'buen pastor"' (G. Alberigo, Breve historia del Concilio Vaticano II, op. cit., p. 38).

38. En la homilía con motivo de su coronación, Juan XXIII encuentra en la Escritura y en la historia su concepción de pastoralidad. En la Escritura: "Hay quien espera en el pontífice al hombre de Estado, el diplomático, el científico, el organizador de la vida colectiva (...) El nuevo papa... es, como el hijo de Jacob, que, encontrándose con sus hermanos de desventuras, les revela la ternura de su corazón y, prorrumpiendo en llanto, dice: 'Soy... vuestro hermano José'. El nuevo pontífice... hace realidad, ante todo en sí mismo, aquella espléndida imagen del Buen Pastor (...) Todo pontificado toma la fisonomía propia del semblante de aquel que lo personifica y representa (...) La enseñanza divina y su gran escuela son resumidos en aquella palabra suya: 'Aprendan de mí que soy manso y humilde de corazón'. La gran ley, por tanto, es la mansedumbre Joannis y la humildad" ("Homilia Joannis PP. XXIII in die coronationis habita", 4.11.1958). La inspiración histórica la encuentra en san Carlos Borromeo, cuya fiesta ocurre justamente el 4 de noviembre, fecha escogida para la coronación: "Función pastoral, reforma y concilio son las tres palabras clave del pontificado del papa Juan que emergen claramente ya en su discurso inaugural" (M. Benigni y G. Zanchi, João XXIII, op. cit., p. 232).

39. La primera afirmación dramática de la libertad del concilio ocurrirá el 13 de octubre, primer día de los trabajos conciliares, cuando se debían escoger los miembros electores de las comisiones conciliares, que, por una maniobra de la curia, podían acabar siendo básicamente los mismos de las respectivas comisiones preparatorias. El cardenal Tisserant presidía la sesión. Al inicio de la votación, el cardenal Liénart, de Lille, pidió la palabra. Tisserant se la negó. Liénart tomó el micrófono y, después de decir "Je la prends tout de même", propuso una moción de aplazamiento, argumentando que los padres conciliares se conocían muy poco y que era necesario más tiempo para tomar decisiones tan comprometedoras. El cardenal Liénart y el cardenal Frings, de Colonia, sugirieron una consulta previa entre los miembros de las diversas circunscripciones eclesiásticas, lo que permitiría un mayor conocimiento de los candidatos. ¡Aplauso ensordecedor! En ese momento, comenta el obispo estadounidense Robert J. Dwyer: "Nos dimos cuenta de ser un concilio y no una clase de alumnos de escuela primaria, reunida al son de tambores" ( $c f$. O. H. Pesch, Il 
Entretanto, el 15 de mayo de 1961, con ocasión del 70. aniversario de la Rerum novarum, Juan XXIII publicó la encíclica Mater et magistra, que, aunque retomaba afirmaciones habituales de la doctrina social de la Iglesia, introducía importantes novedades en comparación con la impostación tradicionalista que estaban dando las comisiones pre-conciliares sobre los mismos temas. La Mater et magistra, de hecho, abandona el método deductivo habitual; utiliza sin reservas el término "socialización", y la comprende sobre todo como un fenómeno de masas; y libera de tonos moralistas temas como propiedad, trabajo, empresa, etc., ya tratados en documentos anteriores.

En Navidad del mismo año — casi tres años después del anuncio—, a través de la constitución apostólica Humanis salutis, Juan XXIII convoca solemnemente el concilio. En este importante texto, el papa enmarca el significado del concilio en su momento histórico, con sus oportunidades y dificultades. Para el pontífice los cambios por los que está pasando el mundo moderno son tan grandes que lo colocan en el umbral de una nueva era: "La Iglesia asiste hoy a la grave crisis de la sociedad. Mientras para la humanidad despunta una nueva era, pesan sobre la Iglesia obligaciones de una gravedad y amplitud inmensas, como en las épocas más trágicas de su historia" ${ }^{\prime 4}$. Su visión de la modernidad no es muy diferente de la de los obispos y papas después de la Revolución francesa. Lo que le diferencia de ellos es el espíritu de fe y la confianza en Cristo y en el Espíritu con que se pone ante esta realidad. De ahí la necesidad de la Iglesia de sentir "el ritmo del tiempo" y distinguir los "signos de los tiempos".

Estas dolorosas realidades llaman al deber de la vigilancia y despiertan el sentido de la responsabilidad. Gente sin confianza solo ven tinieblas sobre el rostro de la tierra. Nosotros, sin embargo, preferimos recomponer nuestra confianza en nuestro Salvador, que no se apartó del mundo redimido por Él. Apropiándonos de la recomendación de Jesús de saber distinguir los "signos de los tiempos" (Mt 16, 3), nos parece vislumbrar, en medio de tanta tiniebla, muchas señales que nos dan una sólida esperanza de tiempos mejores para la Iglesia y para la humanidad. ${ }^{41}$

La convocatoria del concilio se coloca en esa perspectiva:

Ante el doble espectáculo de un mundo que revela un grave estado de indigencia espiritual y de la Iglesia de Cristo, tan vibrante de vitalidad, desde

Concilio Vaticano II, op. cit., p. 83). La sesión fue suspendida; se reunieron los diez presidentes; consultado, Juan XXIII apoyó la idea del aplazamiento. En los días siguientes, las conferencias episcopales se reunieron y prepararon listas electorales, que fueron votadas en la sesión del 16 de octubre, instituyendo, así, comisiones internacionalizadas.

40. Constitución apostólica Humanae salutis, 3.

41. Ibid., 4. 
que accedimos al supremo pontificado, a pesar de nuestra indignidad y por un designio de la Providencia, sentimos el urgente deber de invitar a nuestros hijos a dar a la Iglesia la posibilidad de contribuir más eficazmente a la solución de los problemas de la Edad Moderna. ${ }^{42}$

Por esa razón, el concilio no se debe concentrar "en uno o más puntos de la doctrina católica", sino que se debe abrir "a una verdadera epifanía, a una revelación que no se limita a este o aquel tema, sino que toca todas las cosas, todo el bien dado al cristianismo"43.

Faltando un mes para la solemne apertura, Juan XXIII todavía expresó en un radiomensaje algunas convicciones suyas en relación al gran acontecimiento. (1) El concilio iba a tener lugar en "el momento propicio", es decir, en una de esas "horas históricas de la Iglesia" que propician un nuevo paso hacia adelante. (2) La renovación del encuentro con el rostro de Jesús resucitado, o mejor aún, "retomar con más energía la respuesta del mundo entero, del mundo moderno, al testamento del Señor". (3) La unidad que existió durante siglos entre todos los cristianos interpela a todos los que "no son insensibles al nuevo soplo que despierta el proyecto del concilio" en dirección de la "congregación fraterna" de los cristianos en la única antigua comunión. (4) "Ante los países desarrollados, la Iglesia se presenta como es y quiere ser, como la Iglesia de todos, y particularmente de los pobres" ${ }^{\prime 4}$.

Durante el verano europeo fueron enviados a los obispos, para ser analizados, siete "esquemas" (sobre las fuentes de la revelación, el depósito de la fe, el orden moral, la liturgia, la familia, las comunicaciones sociales y la unidad de la Iglesia). En muchas de las reacciones se notaba la distancia que existía entre las perspectivas abiertas por el papa y la línea de los esquemas. El esquema sobre la liturgia fue el único que obtuvo consenso.

En el período inmediatamente anterior al concilio, se temía que el antiguo espíritu de la fase preparatoria sofocase el concilio soñado por Juan XXIII. ¿Serían capaces los obispos de reaccionar a los "esquemas" que venían de Roma? Los cardenales Suenens y Léger se presentaron al papa para manifestarle con toda claridad esta preocupación.

Para el buen funcionamiento del concilio — que reuniría a cerca 2,500 obispos, más de 500 teólogos y representantes de las iglesias y comunidades no católicas - era necesario establecer los procedimientos que permitiesen la participación de todos y la transparencia de las votaciones. Para ello se elaboró

42. Ibid., 6.

43. ADP I, 44.

44. Radiomessagio del santo padre Giovanni XXIII (11 de septiembre de 1962). Disponible en http://bit.ly/IsgFpP. 
el reglamento de la celebración del concilio, aprobado el 6 de agosto de 1962 y publicado el 5 de septiembre. De hecho, solo llegó al conocimiento de los obispos en vísperas del evento. El referente era el reglamento del Concilio Vaticano I (el cual, a su vez, estaba basado en el sucinto reglamento del Lateranense V). Como es sabido, en ese concilio participó un número mucho menor de obispos, además de haber estado fuertemente condicionado por la actuación de Pío IX ${ }^{45}$. A medida que avanzaban los trabajos conciliares, se sentía la necesidad de modificar las reglas previstas, en lo que también tuvo una participación sabia y decisiva Juan $\mathrm{XXIII}^{46}$. De hecho, aunque él era el responsable último de la preparación y de la alta dirección de los trabajos conciliares propiamente dichos, no tomó ninguna decisión importante para poner las cosas en una dirección que fuera a su gusto. Por lo que toca a la lengua que debía ser utilizada en las sesiones plenarias, decidió que el latín sería la lengua oficial, pero, a pesar de la Veterum sapientia ${ }^{47}$,

45. En la sesión de apertura del Vaticano I participaron 744 obispos. En la votación de la Pastor aeternus, sobre un total de 601 obispos votantes, alrededor de 50 se ausentaron, 88 votaron en contra y 65 "placet iuxta modum". Por lo que toca a la "libertad" del concilio, véase por ejemplo R. Aubert, Vatican I, Éditions de l'Orante, París, 1944, especialmente pp. 243 y ss.

46. En la discusión, por ejemplo, del esquema sobre la revelación elaborado en la fase preparatoria, la mayoría de las intervenciones consideraba el texto inadecuado y, por tanto, que no debería ser usado ulteriormente como base para la discusión (cf. B. Kloppenburg, Concilio Vaticano II, vol. II, op. cit., pp. 161 y ss.). Consultada formalmente la asamblea, la gran mayoría se inclinó a favor de retirar el texto, pero faltaban alrededor de setenta votos para llegar a la mayoría de dos tercios exigidos por el reglamento. Se puede imaginar el impasse: ¡la mayoría de los padres conciliares se vería obligada a debatir un tema tan central como el de la revelación a partir de un texto que rechazaba! Al día siguiente, Juan XXIII por iniciativa propia retiró el esquema e instituyó una comisión que, hasta el segundo período, debería elaborar un nuevo esquema (cf. O. H. Pesch, Il Concilio Vaticano II, op. cit., p. 91).

47. La publicación de la Veterum sapientia (22 de febrero de 1962) fue motivo de desconcierto y consternación. Se trata de un confuso collage de posiciones disparatadas mantenidas unidas por la idea del latín como lengua oficial que "los ambientes más cerrados de la curia consiguieron obtener del papa" (A. Melloni, "Tensioni e timori nella preparazione del Vaticano II. La "Veterum sapientia" di Giovanni XXIII [22 febbraio 1962]", Cristianesimo nella storia, 11 [1990], pp. 275-307). Esto no impidió que en el concilio los padres discutiesen con toda libertad sobre la adopción de la lengua vernácula en la liturgia. Al respecto $-\mathrm{y}$ también en relación a otras situaciones - se habla del "paradójico Juan XXIII" ( $c f$. O. H. Pesch, Il Concilio Vaticano II, op. cit., pp. 59-61.74 y ss). Más allá de convicciones personales, al parecer también tuvieron peso "los mismos principios metodológicos; ante todo, el de valorar lo que une y, no menos, el de la máxima condescendencia posible. Verlo todo, apreciar mucho y corregir poco, un proverbio que le era muy querido, se hacía cada vez más actual y él lo seguía de buen grado. Al mismo tiempo, juzgaba que no se debía abrir la mano en el proyecto anunciado; las resistencias más bien le estimu- 
se podrían usar otras lenguas cuando fuese necesario ${ }^{48}$. El reglamento no hizo caso a esa decisión de Juan XXIII y permitió el uso de otras lenguas solo en las comisiones. Sin embargo, en contra del reglamento, el patriarca Maximos IV Saigh utilizaba el francés en las sesiones plenarias.

Esta última etapa de la preparación estuvo marcada por algunos hechos importantes: (1) la invitación de "observadores" de las iglesias no cristianas; (2) las iniciativas para lograr la participación de los obispos católicos impedidos por el régimen comunista de salir de sus países (polacos, húngaros, rumanos, búlgaros, bálticos, rusos), lo que dará inicio a la llamada Ostpolitik; (3) el simbolismo del fracaso del sínodo romano, que había sido anunciado, junto con el concilio, el 25 de enero de 1959; (4) los encuentros informales entre los futuros padres conciliares.

La presencia de "observadores" que tuvieron participación activa en los trabajos de las comisiones no tiene precedentes en la historia de la Iglesia ${ }^{49}$.

La autorización para que los obispos de los países europeos bajo régimen comunista pudiesen ir a Roma se consiguió con un trabajo muy bien articulado, pues no existían relaciones diplomáticas entre el Vaticano y esos países; y de uno y otro lado, por lo general el clima estaba dominado por la intransigencia y la hostilidad $^{50}$.

El sínodo romano fue un fracaso escandaloso, lo que era síntoma de una profunda crisis en Roma, centro de la cristiandad, "caput mundi", como se solía decir: "La diócesis no estaba preparada y vivía en un estado de disgregación de siglos; buena parte de la estructura del vicariato no sintonizó con los deseos del

laban a precisarlo mejor" (G. Alberigo, Papa Giovanni, op. cit., p. 145). "A propósito de esta actitud constante durante el pontificado, no parece adecuada una explicación de tipo apologético, como sería, por simpatía, responsabilizar al papa Roncalli de todos los actos de apertura y desarrollo, y a la curia romana de los otros. Mediante rigurosos estudios habrá que buscar explicaciones más 'objetivas' y probablemente menos maniqueas. Al tener en cuenta la distinción entre lo que Roncalli juzgaba substancial o accesorio se dispone de otro importante criterio, relacionado con este, como es el de la renuencia continua del aparato curial a adaptarse a ciertas orientaciones del papa" (A. Alberigo y G. Alberigo, Giovanni XXIII, op. cit., p. 24).

48. $C f$. ADP I, 95.

49. Muchos siglos antes de los concilios de León y Florencia, la Iglesia ortodoxa de lengua griega intervino, en cuanto tal; en el concilio de Trento, participaron inicialmente los protestantes, que luego se ausentaron, dada la magnitud y la profundidad de la separación con los católicos; en el Vaticano I, los ortodoxos orientales y los protestantes ignoraron la infeliz invitación de Pío IX ( $c f$. R. Audet, Vatican I, Éditions de l'Orante, París, 1964, pp. 48 y ss.).

50. Cf. G. Alberigo, Papa Giovanni (1881-1963), op. cit., p. 156. 
papa; e incluso el instrumento sinodal tuvo que ser puesto al día"51. Esto no resta méritos a la iniciativa papal ni dejó de producir algunos frutos: fue el primer sínodo romano en toda la Edad Moderna; introdujo en la conciencia eclesial el carácter diocesano de la Iglesia particular de Roma que había desaparecido hacía siglos; muy pocos comprendieron la conciencia que tenía Juan XXIII, frecuentemente expresada, de ser obispo de Roma, y que desde ahí el papa era ministro de la unidad de la Iglesia universal. El papa, con el donaire que le caracterizaba, no dejó de manifestar su insatisfacción con los resultados: "Con la ayuda del Señor, pudimos realizar, ciertamente, un opus bonum, pero, en algunas cosas, no un opus perfectum" 52 . Tal vez temía que el pobre desempeño del sínodo fuese, como querían algunos, una forma de contrarrestar el proyecto del concilio ecuménico que seguía su curso.

Asuntos logísticos muy concretos, alojamiento, alimentación, transporte y otros, facilitaron a los obispos encuentros que al principio eran informales, pero que pronto se fueron formalizando, lo que permitió un crecimiento afectivo y efectivo de la comunión entre los obispos ${ }^{53}$.

La fase preparatoria concluyó con dos gestos de gran poder evocador: una peregrinación a Loreto y a Asís, el 4 de octubre de 1962, lo que, en la intención del papa, era por el "feliz desarrollo de la gran asamblea ecuménica". Loreto evocaba eficazmente la encarnación del Verbo. Asís, el papel de los "pequeños" en la Iglesia y la paz en la tierra ${ }^{54}$. Dos cosas muy queridas para el papa Roncalli.

\section{La apertura solemne: la perenne vitalidad del Evangelio en un cambio de época}

El 11 de octubre de 1962 Juan XXIII inauguró solemnemente el Concilio Ecuménico Vaticano II. En el contexto de la celebración eucarística pronunció el discurso Gaudet mater Ecclesia, que fue, en opinión del historiador de los concilios Giuseppe Alberigo, "el acto más relevante del pontificado juanino y probablemente uno de los más desafiantes y significativos de la Iglesia católica

51. Ibid., p. 152.

52. DMC III, p. 38.

53. En el caso de los obispos brasileños, el hecho de tener la Domus Mariae como "local de morada y trabajo", el Pío brasileiro como "punto de apoyo", y una serie de "redes y relaciones" (CNBB, CELAM, redes según familias religiosas, nacionalidad y lengua, redes de los obispos relacionados a los movimientos laicos, etc.) y de que en Domus Mariae se organizasen conferencias con los exponentes más importantes de la teología y del episcopado mundial que estaban en el concilio, resultó en beneficio intelectual, afectivo y pastoral lo que en el período posconciliar impulsó y facilitó enormemente el ejercicio de la colegialidad episcopal ( $c f$. J. O. Beozzo, A Igreja do Brasil no Concílio Vaticano II [1959-1965], op. cit., pp. 163-219).

54. Cf. DMC IV, 558 y 565. 


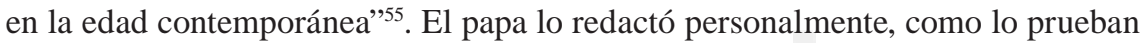
los manuscritos e innumerables testimonios ${ }^{56}$. En ese discurso quiso expresar las convicciones más profundas que le movieron a convocar el concilio.

La primera parte trata, por un lado, de la naturaleza del concilio, su convocatoria y preparación, y por otro, de Cristo, la Iglesia y la historia. El concilio se sitúa ante los "desvíos, exigencias y oportunidades de la Edad Moderna", y es llamado a ser "celebración solemne de la unión de Cristo y de su Iglesia" decir, ocasión para "un conocimiento más amplio y objetivo" de las posibilidades de la Iglesia al servicio de la sociedad y de su futuro. Tiene, por tanto, una actitud de acogida y simpatía, no de condenación. El papa espera que, gracias al concilio, la Iglesia se enriquecerá espiritualmente y mirará al futuro con valentía, "mediante oportunos aggiornamenti". Por ello es necesario discernir los "signos de los tiempos", superando "las insinuaciones de aquellos, ardientes en celo sin duda, pero no dotados de gran sentido de discreción y medida, que no ven en los tiempos modernos más que prevaricación y ruina, y propalan que nuestra época ha empeorado comparada con las anteriores". Por el contrario, afirma el papa, me siento en el deber de "estar en desacuerdo con esos profetas de calamidades, que siempre anuncian acontecimientos infaustos, como si el fin del mundo fuese inminente". El papa dice que está convencido de que la humanidad entera se está encaminando hacia un nuevo ciclo histórico, que lleva en su seno un significado de salvación "inesperado" e "imprevisto".

La segunda parte de la alocución Gaudet mater Ecclesia aborda algunos puntos esenciales: la relación dinámica entre Reino de Dios y sociedad, oportunidad de una reformulación de los datos esenciales de la fe, opción por un estilo de misericordia en vez de severidad ${ }^{58}$, compromiso en busca de la unidad entre los cristianos. El papa no pretende establecer la agenda de los trabajos conciliares. A él le interesa subrayar el espíritu del concilio para aportar una contribución a la transición de la Iglesia hacia una nueva época histórica. Deja claro que el trabajo del concilio no es

la discusión de uno u otro tema de la doctrina fundamental de la Iglesia, repitiendo y proclamando la enseñanza de los Padres y de los teólogos antiguos y modernos... Para esto, no había necesidad de un concilio... El espíritu cris-

55. G. Alberigo, Breve historia del Concilio Vaticano II, op. cit., p. 43.

56. El texto crítico, reconstruido en base a los manuscritos originales, se encuentra en $\mathrm{G}$. Alberigo y A. Melloni, Fede Tradizione Profezia, op. cit., pp. 185-283.

57. El concilio es visto aquí más como una celebración privilegiada del misterio de la Iglesia que como un puro órgano del magisterio y/o de gobierno ( $c f$. G. Dossetti, $I l$ Vaticano II. Frammenti di una riflessione, EDB, Bolonia, 1996, pp. 191-219).

58. “(...) la esposa de Cristo prefiere usar más el remedio de la misericordia que el de la severidad. Cree que satisface mejor las necesidades de hoy mostrando la validez de su doctrina que repitiendo condenaciones" (Gaudet mater Ecclesia VII, 2). 
tiano, católico y apostólico del mundo entero espera un salto hacia adelante ("un balzo inanzi") orientado a una profundización doctrinal y una formación de las conciencias, en perfecta correspondencia con la fidelidad a la auténtica doctrina, estudiada y expuesta, por lo tanto, también a través de las formas de la investigación y la formulación literaria del pensamiento moderno. Una cosa es la sustancia de la antigua doctrina del depositum fidei, y otra es la formulación de su revestimiento: y es eso lo que se debe — con paciencia, si es necesario- tener en cuenta, midiéndolo todo en formas y proporciones de un magisterio de carácter prevalentemente pastoral..$^{59}$

Este es, según Juan XXIII, el elemento central ("punctum saliens") del Vaticano II, para que la Iglesia pueda salir "al encuentro de las necesidades de hoy, mostrando la validez de la doctrina sin recurrir a condenaciones". De este modo, el concilio se coloca no solo en la perspectiva de la unidad de todos los cristianos, sino de toda la humanidad. Se contempla el "gran misterio de la unidad" en una triple dimensión: de los católicos, de todos los cristianos y de las personas de todas las religiones.

La alocución inaugural concluye con una cita de san Cipriano:

La Iglesia, con la aureola de luz divina, envía sus rayos al mundo entero. Es, por tanto, luz única, que se difunde por todas partes sin que quede dividida la unidad del cuerpo. Con su fecundidad extiende sus ramos sobre toda la tierra, difunde siempre, cada vez más, sus afluentes: con todo, una sola es la cabeza, único es el origen, una sola es la madre, copiosamente fecunda; por ella fuimos concebidos, alimentados con su leche, vivimos de su espíritu. (De Catholicae Ecclesia unitate, 5.)

La alocución causó impacto, aunque su alcance —que escapó a la mayoría— solo lentamente fue siendo percibido y analizado ${ }^{60}$.

59. Traducción mía del texto italiano distribuido por la Sala de Prensa del Concilio; las palabras en itálica también son mías. El texto propuesto a la asamblea el 23 de septiembre de 1964 para su revisión se refiere todavía a la versión latina (Juan XXIII escribió de su propio puño en italiano), corregida por la curia, del discurso de Juan XXIII. La versión latina no corresponde al texto original, pues dice que una cosa es "el propio depósito de la fe, o sea, las verdades perennes en nuestra venerable doctrina" y que es otra "la forma bajo la cual estas verdades [plural] son enunciadas". El texto original subraya simplemente:"“(..) la diferencia fundamental ["una es... otra es"] entre el depósito de la fe, tomado aquí como un todo — sin referencias a una pluralidad interna que depende ya de la expresión—, y la forma histórica que toma en esta o en otra época" (C. Theobald, "Nodi ermeneutici dei dibattiti sulla storia del Vaticano II", en A. Melloni y E. G. Ruggieri (eds.), Chi ha paura del Vaticano II?, op. cit., p. 67.

60. No se puede pasar por alto un gesto del papa, aparentemente pequeño, la noche del 11 de octubre. El día debía concluir con una manifestación de antorchas 


\section{Los primeros pasos de un largo y difícil caminar}

Era necesario que "las decisiones del concilio se iniciasen con una amplia declaración, en la que, al estilo del Evangelio y en la perspectiva profética del Antiguo Testamento, se fuera proclamado el designio de salvación... Declaración dirigida a una humanidad en la que grandeza y miseria son, entre errores y flaquezas, una aspiración a la luz del Evangelio... Declaración que proclame más allá de fronteras, razas, regímenes, la unidad fraterna de todos los hombres en el rechazo a soluciones violentas, en el amor y en la paz, signos del Reino de Dios" 61 . El 20 de octubre se pronunció un breve mensaje en esa línea. Ponía el énfasis en la disposición de la Iglesia a servir en solidaridad con las angustias que afligen sobre todo a los más humildes, los más pobres y más débiles, en la afirmación de la dignidad del ser humano, en los temas de paz y justicia social ${ }^{62}$.

Por expresa disposición de Juan XXIII la liturgia fue el primer tema a ser debatido del 22 del octubre al 13 de noviembre. Era sin duda el tema que más había madurado en el amplio movimiento de renovación de la Iglesia que desembocaba en el concilio ${ }^{63}$. Su esquema preparatorio fue también el único

("fiaccolata") de la Acción Católica en la Plaza de San Pedro. "El secretario particular le dijo al papa en su oficina: 'Santidad, no se acerque a la ventana, no hable. A través de las cortinas mire qué espectáculo, la plaza de San Pedro está llena de antorchas, iparece que se ha incendiado!'. Pero Juan XXIII se fue a la ventana, y me dijo poco después: ‘Póngame la estola!'. Y comenzó a hablar, invitando a la multitud a mirar la luna” (L. F. Capovilla, Ricordi dal Concilio, op. cit., p. 73). "Queridos hijos, escucho sus voces. La mía es solo una, pero recoge todas las voces del mundo; y de hecho aquí está representado el mundo. Se diría que esta noche hasta la luna tiene prisa... Obsérvenla en lo alto al mirar este espectáculo... Estamos terminando un gran día de paz... Si les preguntara, si pudiera preguntar a cada uno: ‘De qué parte vienes? Los hijos de Roma, que están aquí especialmente representados, responderían: 'Ah, nosotros somos los hijos más próximos, y tú eres nuestro obispo...'. Mi persona no cuenta nada. Es un hermano el que les habla, un hermano convertido en padre por voluntad de Nuestro Señor... Continuemos, pues, queriéndonos bien, queriéndonos de verdad, viéndonos en el encuentro de esta manera: acogiendo lo que nos une, dejando de lado, si lo hubiese, lo que nos puede crear alguna dificultad... Al volver a casa, encontrarán a sus hijos. Háganles una caricia y díganles: 'Esta es la caricia del papa'. Los que están afligidos sepan que el papa está con sus hijos, especialmente en horas de tristeza y de amargura... Adiós, hijos. ¡A la bendición añado los votos de que tengan una buena noche!”.

61. M. D. Chenu, Diario del Concilio Vaticano II, 1962-1963, Bolonia, 1996 (20 de octubre de 1962).

62. $C f$. H. Fesquet, Diario del concilio, Mursia, 1967, pp. 40 y ss.

63. Schillebeeckx observa sabiamente: "Aunque el Concilio no se haya pronunciado sobre muchas cuestiones que todavía hoy [en 1965, nota del autor] están siendo discutidas por los teólogos, todo lo que durante los últimos treinta años [grosso modo, 1935-1965, nota del autor.] llegó a ser opinión común parte del sensus fidei contemporáneo, podemos decir, fue aprobado, ciertamente por el Concilio" 
que fue aceptado por los obispos como base para los debates. Tuvo una gran mayoría a favor, a pesar de la fuerte resistencia de una minoría contraria a cualquier cambio. Dos elementos emergen con total claridad: la adopción de las lenguas vernáculas en la liturgia y la importancia de la liturgia de la Palabra. La autorización para el uso de las lenguas vernáculas restablecía el contacto entre el culto oficial y el pueblo ${ }^{64}$, que ahora podría escuchar a sus ministros "predicar en nuestras propias lenguas las maravillas de Dios" ( $c f$. Hch 2, 11). La recuperación de la mesa de la Palabra, junto a la mesa del Pan ${ }^{65}$, hizo que la atención del pueblo, de los ministros y de los teólogos, no se fijase exclusivamente alrededor de la liturgia eucarística, única parte de la misa a la que se debía "asistir" para cumplir con el precepto dominical y festivo. En este contexto de reflexiones sobre la liturgia salieron a luz datos teológicos importantes, pero que habían quedado en penumbra durante siglos: la Iglesia local, la eucaristía presidida por el obispo y el presbítero, la participación consciente, activa y fructífera de los fieles. Ante las numerosas enmiendas presentadas y el deseo de Juan XXIII de dar tiempo a que el concilio fuese adquiriendo madurez propia, el 19 de noviembre la conclusión de los trabajos sobre la liturgia fue postergada hasta la próxima sesión del concilio. De este modo se archivaba la idea -ingenua o maliciosa - de que el concilio sería breve y ¡aprobaría, casi por aclamación, los materiales preparatorios!

Pronto también se pudo observar que entre los padres conciliares iba tomando cuerpo una mayoría, es decir, un número muy elevado de votos convergentes sobre los grandes temas del concilio. Este fenómeno no era algo que hubiese sido programado ni controlado — como quieren hacer ver los adversarios empedernidos del Vaticano II- A decir verdad, progresivamente los padres conciliares fueron tomando conciencia de su papel y de los horizontes que iba desvelando el concilio.

El 14 de noviembre, el concilio inició la discusión sobre el esquema de las “fuentes de la revelación". La misma expresión traslucía la polémica con la tesis protestante de la "sola Escritura", también superada de alguna manera al recuperarse en el ámbito católico la importancia de la Biblia en la vida espiritual, en la experiencia eclesial y en la teología. De hecho, prevalecía la opinión de que

(E. Schillebeeckx, La definición tipológica del laico cristiano conforme al Vaticano II, en G. Baraúna [coord.], A Igreja do Vaticano II, Vozes, Petrópolis, 1965, p. 994).

64. Cf. A. Rosmini-Serbati, Delle cinque piaghe della Santa Chiesa, Lugano, 1848.

65. En la toma de posesión de la catedral de Letrán, como obispo de Roma, Juan XXIII centralizó su discurso justamente en los temas de la "palabra" y en el "cáliz", retomados ahora por el concilio. "[Él] resaltó su papel de sacerdote o sumo pontífice, colocándose emblemáticamente entre el Cáliz y el Libro, entre el sacrificio redentor de Cristo y el código de dignidad, de libertad y de salvación del hombre" (L. Capovilla, Ricordi dal concilio, op. cit., p. 68). 
solo la palabra de Dios fuera la fuente primaria de la revelación. Cuando, tras acalorados debates, el 20 de noviembre se votó si se podía aceptar el esquema como base para ulteriores trabajos, 1,368 padres estuvieron en contra. Pero de acuerdo al reglamento se necesitaban dos tercios de los votos, tanto para aprobar un texto como para rechazarlo. Según eso, el esquema debería ser el instrumento de trabajo de la asamblea. Fue entonces cuando, una vez más, apareció la sabiduría de Juan XXIII dispuesto a salvaguardar la libertad del concilio ante actitudes pre-conciliares. Respetando la voluntad inequívoca de la asamblea, decidió que la mayoría, que era necesaria para aprobar un texto, no podía ser exigida para rechazarlo ${ }^{66}$. Entonces, el texto preparatorio fue abandonado y se encargó a una comisión mixta, formada por miembros de la comisión teológica y del secretariado para la unidad, que preparara otro texto. La interpretación papal del reglamento, el crecimiento de la importancia del secretariado presidido por el cardenal Bea y la disminución del peso de la curia romana hicieron que creciera la preocupación entre los grupos alineados con la minoría conciliar.

La última fase de la primera sesión del concilio va del 23 de noviembre al 8 de diciembre. Estaba prevista la discusión de dos esquemas: medios de comunicación social y unidad de la Iglesia. Del primero fue aprobada la sustancia, a condición de que la comisión lo redujera a unas pocas proposiciones esenciales. Por lo que toca al tema de la unidad, por falta de coordinación en la fase preparatoria del concilio, había tres esquemas: uno preparado por la comisión para las iglesias orientales, desde una perspectiva "uniata"; otro elaborado por la comisión teológica; y un tercero, por el secretariado para la unidad. En esta situación, el 1 de diciembre, la cuestión ecuménica fue encomendada al examen de una comisión mixta, formada por la comisión doctrinal, la comisión para las iglesias orientales y el secretariado para la unidad.

El cardenal Ottaviani propuso entonces que se discutiese un brevísimo esquema sobre María. Muchos se opusieron a la idea porque les parecía extraña la discusión sobre María, independientemente de la reflexión sobre la Iglesia. Además, muchos estaban deseosos de comenzar tal reflexión. De hecho,

el éxito del concilio parecía estrechamente ligado al modo como la Iglesia se definiría a sí misma, sobre todo cuando la reforma litúrgica ya había anticipado algunas grandes ideas sobre la concepción de la Iglesia que corregían expresiones de los últimos siglos excesivamente institucionales y juridicistas. ${ }^{67}$

Fue así como, durante seis sesiones, a partir del 1 de diciembre, el concilio se dedicó a discutir el esquema sobre la Iglesia. Quedaba claro que, en apenas

66. Cf. ibid., p. 71.

67. G. Alberigo, Breve historia del Concilio Vaticano II, op. cit., p. 52. 
dos meses, la conciencia conciliar había hecho enormes avances; la asamblea ya estaba en condiciones de expresar sus propias convicciones y de reconocerse en líderes que las materializaban. El proyecto sobre la Iglesia era de los mejores, pero, aun así, no agradó y recibió severas críticas: poca sintonía con la eclesiología renovada que se venía construyendo desde mucho antes del concilio; la hegemonía de una comprensión societaria de la Iglesia en perjuicio de una comprensión mistérica; ausencia de sensibilidad ecuménica; presentación del episcopado en línea de dependencia y no de comunión. Las intervenciones de Suenens y Montini propugnaban que toda la obra conciliar girase alrededor de dos ejes fundamentales: la Iglesia "ad intra" y la Iglesia "ad extra"; la identidad de la Iglesia (¿Ecclesia, quid dicis de te ipsa?) y la misión de la Iglesia (¿Ecclesia, quid agis?). Lercaro, en una de las últimas sesiones, sugirió que la idea dominante del trabajo conciliar ("el elemento de síntesis, el punto de iluminación y de coherencia de todos los temas hasta aquí tratados") fuese la Iglesia de los pobres, tesis ya anunciada por Juan XXIII. También se hicieron numerosas críticas al espíritu de gueto, triunfalismo y clericalismo subyacentes al esquema. Junto a la presentación de la Iglesia como misterio en sentido bíblico-patrístico, se proponía también la consideración de la Iglesia como pueblo de Dios.

El debate sobre la Iglesia fue uno de los momentos álgidos del primer período. El concilio se interrogaba sobre las cuestiones de fondo. Los padres tomaban cada vez mayor conciencia de que el evento conciliar no podía restringirse a la vida interna de la Iglesia, sino que debía tener un horizonte mucho más amplio.

La nueva condición de la Iglesia como comunidad abierta, humanamente indefensa, disponible a las necesidades humanas, que había delineado el discurso de apertura, iba adquiriendo contornos cada vez más concretos y decididos. Una apretada serie de intervenciones, desde perspectivas diversas pero complementarias, fue dejando en claro que la conciencia cristiana contemporánea se debía caracterizar en modos sustancialmente distintos al espíritu del esquema preparatorio. ${ }^{68}$

Ni siquiera fue necesario someter a votación el esquema preparatorio como instrumento de trabajo. Fue abandonado elegantemente. En el horizonte del concilio emergía una nueva eclesiología ${ }^{69}$.

\section{Cómo evaluar el período juanino del concilio}

Hubo luces y sombras. Entre las luces, destacan los siguientes aspectos. El clima de libertad en que pudieron trabajar los padres conciliares; las pocas,

68. Ibid., p. 53.

69. Cf. A. Acerbi, Due ecclesiologie. Ecclesiologia giuridica ed ecclesiologia di comunione nella "Lumen gentium”, EDB, Bolonia, 1975. 
pero sabias y oportunas actitudes adoptadas por Juan XXIII, para garantizar la libertad y el buen funcionamiento de la asamblea; el rechazo de los esquemas preparatorios y de las maniobras curiales; la convocatoria de los teólogos censurados durante el pontificado de Pío XII; el intercambio creciente entre obispos, lo que hizo que las experiencias de cada uno, las diferencias culturales y las diversas sensibilidades contribuyeran al ejercicio afectivo y efectivo de la colegialidad; los contactos, inicialmente casuales, pero más tarde programados, entre obispos y teólogos, propiciando un "aggiornamento" teológico impensable, dadas las distancias geográficas, culturales e ideológicas en que se encontraban los obispos por lo general; la forma evangélica de Juan XXIII de ejercer el ministerio petrino. Con todo, no faltaron sombras. La hegemonía de la curia en la comisión teológica y en las comisiones temáticas, lo que solo poco a poco fue disminuyendo; las dimensiones de la comisión inicial de la presidencia; la falta de coordinación de los trabajos preparatorios; la impresión de que el concilio no tenía una agenda clara y no estaba en condiciones de llegar a indicaciones precisas; las presiones y críticas que intentaban desacreditar la persona de Juan XXIII y su proyecto.

La aproximación de una pausa en los trabajos conciliares y la enfermedad del papa produjeron serias preocupaciones en quienes se habían adherido al proyecto conciliar. Sin embargo, se tomaron varias iniciativas para garantizar la continuidad de dicho proyecto. Los grupos liderados por el cardenal Suenens, en su vertiente más teológica; el grupo "Jesús, la Iglesia y los pobres", surgido por iniciativa del expadre obrero Gauthier y presidido por el cardenal francés Gerlier, en el que participaban el cardenal Lercaro y don Hélder Câmara; el grupo de Bolonia, que más allá del liderazgo de Lercaro contaba con personas del peso de Dosseti y Alberigo; todos esos grupos tomaron iniciativas para garantizar que durante el largo período de pausa en el trabajo de las comisiones se mantuviesen las orientaciones dadas por Juan XXIII, que eran compartidas por muchos obispos. También el papa, en su momento, estableció criterios para que la actividad conciliar prosiguiese entre el primero y el segundo período conciliar y creó una comisión de coordinación (Confalonieri, Döpfner, Liénart, Spellman, Suenens y Ubani), para asegurar el buen desarrollo del proceso, sobre todo en esa fase en que quedaba suspendida la asamblea ${ }^{70}$. Finalmente, la carta del pontífice Mirabilis ille a todos los obispos, en la Epifanía de 1963, dejaría aún más explícita

70. Esta comisión, a cuyos miembros iniciales Pablo VI incorporó a Agagianian, Lercaro y Roberti, se reunió cinco veces antes de la reapertura del concilio. En la primera reunión (del 21 al 27 de enero de 1963) redujo los esquemas preparatorios de setenta y dos a solo diecisiete, que habían sido reelaborados. Por fin el Vaticano II "se liberaba de la hipoteca de los trabajos preparatorios, aunque muchos elementos y varias formulaciones de aquellos trabajos hayan sido repescados en los textos sometidos sucesivamente al concilio" (ibid., p. 57). 
y definitiva la sintonía entre el papa y la gran mayoría conciliar: "El concilio recibe sus directrices del papa que lo convocó, pero cabe a los obispos tutelar su libre desarrollo... cabe a los padres conciliares proponer, discutir, preparar en la

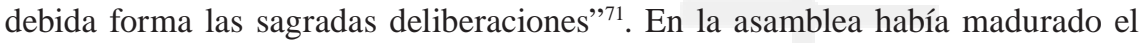
clima, y en la opinión pública se percibía cada vez con mayor claridad el alcance del concilio y del cambio que estaba promoviendo.

Al concluir el primer período del concilio (8 de diciembre de 1962), Juan XXIII dejó claro que la suspensión de la asamblea no significaba "en modo alguno la interrupción del trabajo, como tampoco lo fue en otros concilios durante las pausas; por el contrario, lo que nos espera será mucho más relevante... El concilio continuará abierto en los próximos nueve meses de suspensión de sesiones ecuménicas propiamente dichas". Quedaba clara la disposición del papa de que el concilio tuviese continuidad, retomando sus trabajos el 8 de septiembre de 1963, con o sin él.

De hecho, ya sin él, gravemente enfermo desde $1962^{72}$. En los primeros meses del 63, su estado de salud se agravó, lo que no le impidió seguir de cerca los trabajos de la comisión de coordinación y de las comisiones conciliares; recibir a la hija de Kruschev y a su yerno Alexei Adjubei, redactor jefe del diario soviético Pravda (7 de marzo); publicar la memorable Pacem in terris (11 de abril, Jueves Santo), dirigida no solo a los fieles católicos, sino "a todos los hombres de buena voluntad"; recibir el Premio Balzan de la Paz (10 de mayo); entonar, por última vez, el jueves de la Ascensión (23 de mayo), con voz todavía fuerte y musical, el Regina Coeli, seguido de aplausos tan prolongados que casi le impidieron dar la bendición.

\section{La muerte de un cristiano papa}

El 28 de mayo, al secretario de Estado, quien le comunica que el mundo entero está rezando por él, el papa le responde: "Dado que el mundo reza por el papa enfermo, es natural que le dé una intención a estas súplicas. Si Dios quiere el sacrificio de la vida del papa, que eso sirva para implorar abundantes favores sobre el concilio ecuménico, sobre la Iglesia santa, sobre la humanidad que aspira a la paz"73.

En la crónica de su prolongada agonía se registran sus últimas palabras:

Este es un altar... Tengo ante mí la visión clara de mi alma, de mi sacerdocio, del concilio, de la Iglesia universal... Estoy tranquilo. Siempre fue mi deseo hacer la voluntad de Dios, siempre, siempre... Quiero morir sin saber si poseo

71. Mirabilis ille 12.

72. El 29 de octubre de 1962 — dieciocho días después de abrir el concilio- el Vaticano dio la primera noticia de que el papa tenía una grave enfermedad en el estómago.

73. L'Osservatore Romano, 29 de mayo de 1963. 
algo que me pertenece... El Evangelio no cambió, somos nosotros quienes empezamos a comprenderlo mejor... El mundo despertó. Poco a poco la purísima doctrina de la encíclica [Pacem in terris], doctrina expuesta con amabilidad, encontrará el camino de las conciencias... No, no me aflijo por lo que se escribió y se dice sobre mí. Eso es muy poco en comparación con las angustias de Jesús, Hijo de Dios, durante toda su vida y en la cruz... Déjenme ahora a solas con mi Señor... ¡Ut unum sint. Ut unum sint!

La desaparición del papa —el 3 de junio de 1963, día de Pentecostés- constituyó un acontecimiento espiritual que afectó inesperadamente a gran parte de la humanidad. Él abrió una época nueva en la Iglesia, volvió a proponer los temas esenciales de la caridad y de la unidad, estrechamente ligados a los de la renovación de la actitud espiritual, de las estructuras eclesiales, y también de la reformulación de la doctrina" ${ }^{\text {" }}$.

\section{Algunos testimonios}

Muchos, que durante la elección y los primeros días del pontificado de Juan XXIII se mostraron decepcionados, a la espera de, quién sabe, un Pío XIII pues Pío XII, para muchos, era insuperable-, pronto modificaron su postura y reconocieron lo inapropiado de sus valoraciones anteriores ${ }^{75}$; algunos de ellos llegaron incluso a expresar un amor apasionado por el papa del concilio. En este sentido, es ejemplar el testimonio de Alceu Amoroso Lima.

En una de sus primeras reacciones escribió:

Dos, o más bien tres grandes papas [Pío XI, Pío XII y Pío XIII], uno tras otro, hubiese sido tal vez una medicina demasiado fuerte para la Iglesia y para el mundo. Vamos a respirar un poco. Vamos a fumar un cigarrillo. Vamos a estirar las piernas. Durante el intervalo vamos a dar una vuelta por el foyer. Nuestro buen Juan XXIII, mi tocayo gordo y bonachón, va a permitir que la gente respire un poco después de todo lo que, constantemente y con toda intención, Pío XII lanzó sobre nuestras cabezas (...) Juan XXIII es un intervalo, un descanso, un banquillo, un vaso de agua, una mecedora después de la tremenda carrera que Pío XI y Pío XII nos obligaron a correr. Andábamos con la lengua fuera. El Espíritu Santo lo vio desde arriba. Y

74. G. Alberigo, Breve historia del Concilio Vaticano II, op. cit., p. 61.

75. Carta de Alceu Amoroso Lima a su hija benedictina María Teresa Amoroso Lima: "Y qué lección para nosotros que depositamos en él tanta esperanza, después de considerarlo, al principio, como una... salida al impasse de la elección. En estos cuatro años se reveló como un hombre providencial para la Iglesia, para el mundo, y tan de acuerdo con todo lo que algunos de nosotros deseábamos desde el fondo del corazón..." (Río, 23 de diciembre de 1962); en A. A. Lima, João XXIII, Livraria José Olympio Editora, Río de Janeiro, 1966, p. 102. 
decidió tocar el tambor para anunciar un tiempo de reposo. Sin duda, son los caminos que llevan a la Iglesia a construir el Reino de Dios. Pero para caminar es necesario aliento, y mi bondadoso tocayo nos dejará tomar aliento, dándonos algún tiempo para que se haga un balance de la inmensa obra de sus dos predecesores. ${ }^{76}$

Algún tiempo después de la publicación de la Mater et magistra, expresó: "Los medios vaticanos están impregnados del más completo conservadurismo. Y Juan XXIII, para publicar la Mater et magistra, debe haber escuchado solamente la voz del Espíritu Santo, y hacer un verdadero milagro para salir de ese engranaje" ${ }^{7}$. Comentando el eco de la alocución de apertura del concilio en la prensa francesa, dijo que "la 'revolución' que el papa provocó con su discurso, que todo el mundo esperaba que fuese una alocución convencional, acabó siendo una 'bomba' con la condena de los 'integristas' y 'conservadores"'78. Y escribió pidiendo a la comunidad de su hija benedictina oraciones por la salud del papa, "doblemente importante para nosotros por ser el papa y por ser (...) Juan XXIII. Si él llega a faltar mediado el concilio, o antes, sin que el concilio decida cosa alguna $[. .$.$] ¿qué va a pasar?"79. "Don Hugo me decía ayer: "Este papa solo tiene$ un defecto: no haber nacido 20 años antes" ${ }^{80}$. Después del "manifiesto de los obispos”, dijo: "¿Cuándo nuestro episcopado escribiría lo que ahí está, si no fuese por nuestro Juan XXIII?"'1 . En la víspera de la muerte de Juan XXIII: “(...) el nuevo rumbo que nuestro 'buen Juan' imprimió a la barca, muriendo rodeado del amor y del respeto de todos y volviendo a poner a la Iglesia tras los pasos de Jesús y de Juan" 82 . Al día siguiente: "Sea como fuere, será imposible un nuevo papa tan fino como el que acaba de dejarnos, que a mi juicio fue el que más conviene a la Iglesia en este momento" 83 . Algunos días después: "De cualquier modo, lo que hizo nuestro Juan XXIII nadie más lo podrá hacer... Un santo que abrió el siglo XXI" ${ }^{84}$. Y para concluir, las preguntas que se hacía un día antes del entierro de Juan XXIII:

76. Carta de Alceu de Amoroso Lima a su familia (Nueva York, 29 de octubre de 1958), ibid., p. 12. En las citas siguientes de nuestro texto se mencionará dónde fue escrita la carta, la fecha de la misma y la página de la obra de Alceu ya citada.

77. Roma, 10 de octubre de 1962, p. 84.

78. Roma, 15 de octubre de 1962, p. 89. París, 1 de diciembre de 1963, p. 96.

79. París, 1 de diciembre de 1962, p. 99.

80. A bordo del Augustus, 9 de diciembre de 1962, p. 99.

81. Río de Janeiro, 3 de mayo de 1963, p. 114. Lo que el autor califica como "manifiesto de los obispos" es el Mensaje del Episcopado Brasileño con ocasión del $1^{\circ}$ de Mayo de 1963 (cf. ibid., pp. 216 y ss.).

82. Río de Janeiro, 2 de junio de 1963, p. 119.

83. Río de Janeiro, 4 de junio de 1963, p. 121.

84. Río de Janeiro, 7 de junio de 1963, p. 123. 
Por más que intente callar la voz que surge de lo escondido, no consigo quitarme de encima el pensamiento de lo que fueron estos cuatro años y medio que ;hicieron progresar a una Iglesia de 400 años! Cuando pienso en esos cuatro años, comienzo a considerarlos como algo irreal, trop beau pour être vrai. Y sigo pensando: ¿será que realmente hemos vivido esos cuatro años? ¿Será que realmente hubo un hombre llamado Juan XXIII? ${ }^{85}$

85. Río de Janeiro, 16 de junio de 1963, p. 129. 